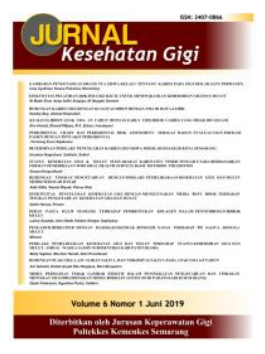

\title{
HUBUNGAN TINGKAT PENGETAHUAN DENGAN PERILAKU PEMELIHARAAN KESEHATAN GIGI DAN MULUT MURID SEKOLAH DASAR
}

\author{
Aida Silfia ${ }^{1}$ Slamet Riyadi $^{2}$ Pahrur Razi ${ }^{3}$ \\ ${ }^{123}$ Jurusan Keperawatan Gigi Poltekkes Kemenkes Jambi, Indonesia \\ Corresponding author: Aida Silfia \\ Email: yadiegigi@yahoo.co.id

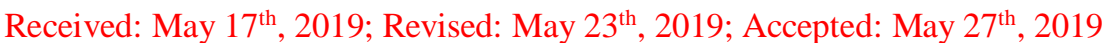

\begin{abstract}
One of the causes of oral problems is the oral hygiene neglect. Despite the high knowledge in oral health care, lot of children still unable to improve their attitude and practice towards oral health care. The aim of this study is to define the association of knowledge level with behaviour towards oral health care in students of SDN 36/IV Jambi in 2018. This is a cross sectional study comprised of 59 subjects recruited by total sampling method. Data collected from questionnaire filled by subjects followed by chi square analysis. The high, moderate and low knowledge level of SDN 36/IV Jambi students were 66,1\%, 32,2\% and 1,7\% respectively. 67,8\% subjects had good behaviour towards oral health care, while the other $32,2 \%$ had moderate behaviour. No significant association found between knowledge level and behaviour towards oral health care in students of SDN 36/IV Jambi in 2018 ( $\operatorname{sig}=0,446 ; p<0,05$ ).
\end{abstract}

Key words: Tingkat Pengetahuan; Perilaku Pemeliharaan Kesehatan Gigi; Sekolah Dasar

\section{Pendahuluan}

Kesehatan adalah elemen terpenting dalam kehidupan yang sangat dibutuhkan oleh manusia. Undang-Undang Kesehatan Nomor 36 Tahun 2009 pasal 1 yang berbunyi keadaan sehat, baik secara fisik, mental, spritual, maupun sosial yang memungkinkan setiap orang untuk hidup produktif secara sosial maupun ekonomis (Kemenkes, 2012).

Kesehatan mulut merupakan hal penting untuk kesehatan secara umum dan kualitas hidup. Kesehatan mulut berarti terbebas kanker tenggorokan, infeksi dan luka pada mulut, penyakit gusi, kerusakan gigi, kehilangan gigi dan penyakit lainnya, sehingga terjadi gangguan yang membatasi dalam mengigit, mengunyah, tersenyum dan berbicara, World Health Organization (WHO, 2012). Hasil Riset Kesehatan Dasar(Riskesdas) 2013, menunjukkan indeks karies gigi di Indonesia sebesar 4,6 dan 5,5 terjadi di Provinsi Jambi.
Masalah kesehatan gigi di Indonesia masih memerlukan perhatian yang sangat serius karena prevalensi karies dan penyakit periodontal mencapai $80 \%$ dari jumlah penduduk. Upaya untuk mengatasinya sampai saat ini belum menunjukkan hasil yang memuaskan. Hal ini dapat dilihat dari indikator kesehatan gigi masyarakat, yaitu rata-rata karies di Indonesia 6,4 (Herijulianti, 2002).

Notoatmodjo (2007), menjelaskan bahwa penyebab timbulnya masalah kesehatan gigi dan mulut pada masyarakat salah satunya adalah mengabaikan kebersihan gigi dan mulut. Hal tersebut dilandasi oleh kurangnya pengetahuan akan pentingnya pemeliharaan gigi dan mulut. Anak masih sangat tergantung pada orang dewasa dalam hal menjaga kebersihan gigi karena kurangnya pengetahuan anak mengenai kesehatan gigi dibandingkan orang dewasa.

Pada umumnya keadaan kebersihan mulut anak lebih buruk dan anak lebih banyak makanmakanan dan minuman yang menyebabkan karies 
dibanding orang dewasa. Anak-anak umumnya senang gula-gula, apabila anak terlalu banyak makan gula-gula dan jarang membersihkannya, maka gigigiginya banyak mengalami karies (Machfoedz, 2005).

Sekolah Dasar Negeri (SDN) 36/IV beralamat di jalan Pangeran Hidayat RT. 18 Kelurahan Suka Karya Kota Jambi. Setelah di lakukan wawancara dan survei dengan pihak sekolah, sekolah tersebut telah dilaksanakan program pelayanan asuhan kesehatan gigi dan mulut dan sikat gigi massal, oleh tenaga kesehatan gigi dari Puskesmas Paal V Kota Jambi. Tenaga kesehatan datang hanya 6 bulan sekali untuk melakukan kegiatan rutin disekolah dengan kegiatan pemeriksaan kesehatan tubuh, penyuluhan tentang kesehatan, termasuk kesehatan gigi dan mulut. Sekolah Dasar 36 Kota Jambi memiliki UKGS dan UKS yang cukup memadai.

Berdasarkan uraian diatas, penulis tertarik untuk melakukan penelitian tentang hubungan tingkat pengetahuan dengan pemeliharaan kesehatan gigi dan mulut muri SDN 36/IV Kota Jambi.

Menurut Green (1980) dalam Notoatmodjo (2012), perilaku ditentukan oleh 3 faktor yaitu : faktor predisposisi (predisposing factor) yang terwujud dalam pengetahuan, sikap, kepercayaan, keyakinan, nilai-nilai, dan sebagainya; faktor pendukung (enabling factor) yang terwujud dalam lingkungan fisik, tersedia atau tidak tersedianya fasilitas-fasilitas atau sarana-sarana kesehatan; faktor pendorong (reinforcing factor) yang terwujud dalam sikap dan perilaku, yang merupakan kelompok referensi dari perilaku masyarakat.

\section{Metode Penelitian}

Jenis penelitian ini adalah penelitian kuantitatif dengan motode penelitian yang digunakan adalah studi cross sectional (potong lintang) yang bertujuan untuk melihat korelasi antara variabel independen dan dependen pada waktu yang bersamaan (Pratiknya, 2007). Populasi penelitian ini adalah murid kelas Va dan Vb SDN 36/IV Kota Jambi sebanyak 59 orang. Teknik pengambilan sampel adalah total sampling, dimana seluruh populasi dijadikan sampel (Sugiyono, 2010). Dan jumlah sampel pada penilitian ini sebanyak 59 orang murid yang bersedia mengikuti penelitian secara penuh.
Analisa bivariat merupakan analisa data yang dilakukan terhadap dua variabel yang diduga berhubungan atau berkorerasi (Sibagariang, dkk, 2010). Variabel yang diduga yaitu hubungan antara tingkat pengetahuan dengan perilaku pemeliharaan kesehataan gigi dan mulut melalui uji statistik yaitu chi sguare. Untuk mengetahui hubungan anatara variabel dengan batas kemaknaan $\mathrm{p} \leq 0,05$ (Hidayat, 2012).

\section{Hasil dan Pembahasan}

Penelitian mengenai hubungan tingkat pengetahuan dengan perilaku pemeliharaan kesehatan gigi dan mulut pada murid kelas VA dan kelas VB SDN 36/IV Kota Jambi tahun 2018 yang dilakukan pada tanggal 19-20 Maret 2018, dengan jumlah sampel 59 orang diperoleh hasil sebagai berikut.

Tabel 4.1

Distribusi Frekuensi Responden Berdasarkan Kelas pada SDN 36/IV Kota Jambi Tahun 2018

\begin{tabular}{cccc}
\hline NO & Kelas & N & \% \\
\hline 1 & Kelas VA & 30 & 50,9 \\
\hline 2 & Kelas VB & 29 & 49,1 \\
\hline & Total & 59 & 100 \\
\hline
\end{tabular}

Berdasarkan tabel 4.1 distribusi responden berdasarkan kelas diketahui bahwa jumlah murid kelas VA sebanyak 30 anak $(50,9 \%)$ dan kelas VB sebanyak 29 anak $(49,1 \%)$.

Tabel 4.2

Distribusi Frekuensi Responden Berdasarkan Jenis Kelamin Kelas VA dan Kelas VB SDN 36/IV Kota Jambi tahun 2018

\begin{tabular}{cccc}
\hline NO & Jenis Kelamin & N & \% \\
\hline 1 & Laki-laki & 29 & 49,1 \\
\hline 2 & Perempuan & 30 & 50,9 \\
\hline & Total & 59 & 100 \\
\hline
\end{tabular}

Tabel 4.2 menunjukkan bahwa jumlah responden penelitian berjenis kelamin laki-laki sebanyak 29 anak $(49,1 \%)$ dan perempuan sebanyak 30 anak $(50,9 \%)$.

Analisis data secara univariat dilakukan terhadap variabel dari hasil penelitian yaitu tingkat pengetahuan murid kelas VA dan kelas VB SDN 36/IV Kota Jambi dengan perilaku pemeliharaan kesehatan gigi dan mulut, dari hasil penelitian 
didapatkan gambaran karakteristik variabel penelitian sebagai berikut:

Tabel 4.3

Distribusi Frekuensi Responden Berdasarkan Tingkat Pengetahuan SDN 36/IV Kota Jambi tahun 2018

\begin{tabular}{cccc}
\hline NO & Tingkat Pengetahuan & N & \% \\
\hline 1 & Tinggi & 39 & 66.1 \\
\hline 2 & Sedang & 19 & 32,2 \\
\hline 3 & Rendah & 1 & 1,7 \\
\hline & Total & 59 & 100 \\
\hline
\end{tabular}

Hasil analisis tingkat pengetahuan murid kelas VA dan kelas VB SDN 36/IV Kota Jambi yaitu, tingkat pengetahuan tinggi yaitu 39 anak $(66,1 \%)$, dan tingkat pengetahuan sedang 19 anak $(32,2 \%)$, sedangkan tingkat pengetahuan rendah 1 anak $(1,7 \%)$. Hal ini menunjukkan tingginya pendidikan seseorang berarti tinggi pula tingkat pengetahuannya. Tetapi seseorang memiliki tingkat pengetahuan tinggi, belum tentu sikap dan perilakunya terhadap suatu keadaan atau situasi itu baik.

Tabel 4.4

Distribusi Frekuensi Responden Berdasarkan Perilaku Pemeliharaan Kesehatan Gigi dan Mulut SDN 36/IV Kota Jambi tahun 2018

\begin{tabular}{cccc}
\hline NO & $\begin{array}{c}\text { Perilaku Pemeliharaan } \\
\text { Kesehatan Gigi dan } \\
\text { Mulut }\end{array}$ & N & $\mathbf{\%}$ \\
\hline 1 & Baik & 40 & 67,8 \\
\hline 2 & Cukup & 19 & 32,2 \\
\hline 3 & Kurang baik & 0 & 0 \\
\hline & Total & 59 & 100 \\
\hline
\end{tabular}

Hasil analisis tingkat pengetahuan murid kelas VA dan kelas VB SDN 36/IV Kota Jambi yaitu, perilaku pemeliharaan kesehatan gigi dan mulut baik sebanyak 40 anak $(67,8 \%)$, dan cukup 19 anak $(32,2 \%)$, dan tidak ada berkreteria kurang baik.

Hubungan antara variabel independen dan variabel dependen dilihat dengan melakukan analisis bivariat menggunakan uji Chi-Square.

Tabel 4.5

Distribusi Frekuensi Responden Berdasarkan Hubungan Tingkat Pengetahuan dengan Perilaku Pemeliharaan Kesehatan Gigi dan Mulut pada SDN 36/IV Kota Jambi tahun 2018

\begin{tabular}{|c|c|c|c|c|c|c|c|c|c|}
\hline \multirow{3}{*}{$\begin{array}{l}\text { Tingkat } \\
\text { Pengeta } \\
\text { huan }\end{array}$} & \multicolumn{6}{|c|}{$\begin{array}{c}\text { Perilaku pemeliharaan } \\
\text { kesehatan gigi dan } \\
\text { mulut }\end{array}$} & \multirow{2}{*}{\multicolumn{2}{|c|}{$\begin{array}{c}\text { Tota } \\
1\end{array}$}} & \multirow{2}{*}{$\begin{array}{c}\mathbf{P} \\
\text { Val } \\
\text { ue }\end{array}$} \\
\hline & \multicolumn{2}{|c|}{ Baik } & \multicolumn{2}{|c|}{$\begin{array}{c}\text { Cuku } \\
\text { p }\end{array}$} & \multicolumn{2}{|c|}{$\begin{array}{c}\text { Kura } \\
\text { ng } \\
\text { Baik }\end{array}$} & & & \\
\hline & $\mathbf{N}$ & $\%$ & $\mathbf{N}$ & $\%$ & $\mathbf{n}$ & $\%$ & $\mathbf{N}$ & $\%$ & \\
\hline Tinggi & $\begin{array}{l}2 \\
8\end{array}$ & 70 & $\begin{array}{l}1 \\
1\end{array}$ & $\begin{array}{r}57 \\
, 9\end{array}$ & 0 & 0 & $\begin{array}{l}3 \\
9\end{array}$ & $\begin{array}{l}6 \\
6\end{array}$ & \\
\hline Sedang & $\begin{array}{l}1 \\
1\end{array}$ & $\begin{array}{r}27 \\
5 \\
\end{array}$ & 8 & $\begin{array}{l}42 \\
, 1\end{array}$ & 0 & 0 & $\begin{array}{l}1 \\
9 \\
\end{array}$ & $\begin{array}{l}3 \\
2 \\
\end{array}$ & \\
\hline Rendah & 1 & $\begin{array}{l}2 . \\
5\end{array}$ & 0 & 0 & 0 & 0 & 1 & $\begin{array}{l}1 \\
7\end{array}$ & $\begin{array}{l}0,4 \\
46\end{array}$ \\
\hline Jumlah & $\begin{array}{l}4 \\
0\end{array}$ & $\begin{array}{c}10 \\
0\end{array}$ & $\begin{array}{l}1 \\
9\end{array}$ & $\begin{array}{c}10 \\
0\end{array}$ & 0 & 0 & $\begin{array}{l}5 \\
9\end{array}$ & $\begin{array}{l}1 \\
0 \\
0\end{array}$ & \\
\hline
\end{tabular}

Dari hasil analisis hubungan dari tingkat pengetahuan dengan perilaku pemeliharaan kesehatan gigi dan mulut diperoleh bahwa 28 anak (70\%) yang memiliki perilaku pemeliharaan kesehatan gigi dan mulut baik, sebanyak 11 anak $(57,9 \%)$ yang perilaku pemeliharaan kesehatan gigi dan mulutnya cukup, dan tidak ada berkreteria kurang baik pada perilaku pemeliharaan kesehatan gigi dan mulut. Sedangkan di antara anak yang tingkat pengetahuannya rendah ada 1 anak $(27,5 \%)$ dengan perilaku pemeliharaan kesehatan gigi dan mulut berkategori baik, dan tidak ada yang berkreteria kurang baik pada perilaku kesehatan gigi dan mulut cukup, dan tidak ada yang berkreteria kurang baik dengan perilaku kesehatan gigi dan mulut, dan tingkat pengetahuannya sedang ada 11 anak $(27,5 \%)$ berkriteria baik dan 8 anak $(42,1 \%)$ berkriteria cukup.

Hasil uji statistik diperoleh nilai p.value $=$ 0,446, maka dapat disimpulkan tidak terdapat hubungan antara tingkat pengetahuan dengan perilaku pemeliharaan kesehatan gigi dan mulut pada murid kelas VA dan kelas VB SDN 36/IV Kota Jambi.

Berdasarkan hasil penelitian yang diuraikan pada Bab IV, pada bab ini peneliti ingin membahas tentang keterbatasan penelitian dan di lanjutkan dengan pembahasan hubungan tingkat pengetahuan dengan perilaku pemeliharaan kesehatan gigi dan mulut murid SDN 36/IV Kota Jambi.

\section{A. Keterbatasan Penelitian}

Proses pengumpulan data peneliti di bantu oleh 2 orang mahasiswa keperawatan gigi dan di lanjut dengan cara pengisian kuesioner oleh responden yaitu siswa-siswi kelas VA dan kelas VB SDN 36/IV Kota Jambi. Kuesioner yang berhasil dikumpulkan sebanyak 59 kuesioner, peneliti 
menemui kendala dimana saat pengisian kuesioner pada responden yang dilakukan didalam kelas responden kurang fokus dan sebagiannya responden kurang bisa di ajak kerja sama terhadap pengisian kuesioner.

\section{B. Tingkat Pengetahuan}

Hasil penelitian menunjukkan bahwa tingkat pengetahuan kesehatan gigi dan mulut SDN 36/IV Kota Jambi memiliki pengetahuan yang cukup tinggi. Hal ini dapat dilihat pada tabel 4.3 bahwa sebesar $66,1 \%$ pengetahuan anak berkriteria tinggi, dan $32,2 \%$ berkriteria sedang, dan $1,7 \%$ berkriteria rendah. Hasil penelitian ini menyatakan pengetahuan seseorang bisa diperoleh secara alamiah maupun secara terencana yaitu melalui proses pendidikan. Secara ilmiah bisa diperoleh berdasarkan pengalaman pribadi, atau mendengar keluhan orang tentang sakit dan cara mengatatasinya. Oleh karena pengalaman tersebut maka orang tersebut berusaha untuk mendapatkan pengetahuan tentang cara memelihara kesehatan dan upaya-upaya mencegah supaya tidak sakit. Pengetahuan kesehatan yang diperoleh melalui proses pendidikan (baik formal, informal maupun nonformal) yang terencanah dan terarah akan lebih mempercepat proses perubahan perilaku kesehatan seseorang atau kelompok masyarakat, Budiharto (1995.

Hal ini dapat terjadi disebabkan karena ada tingkat pengetahuan kesehatan gigi dan mulut, diperkirakan anak sudah mampu membaca dan menyerap informasi dengan jelas dari berbagai media . Menurut Herijulianti (2002), media merupakan alat/saran untuk menyampaikan dan menerapkan pesan yang diperoleh dan yang ditujuh, biasa melalui media massa (surat kabar, majalah, radio, televisi) maupun media antar pribadi (telepon atau surat kabar).

Meskipun memiliki pengetahuan yang cukup tinggi tentang pemeliharaan kesehatan gigi dan mulut, namun anak masih banyak yang belum mengetahui cara meningkatkan pengetahuan terhadap kesehatan gigi dan mulut. Menurut Benyamin Bloom (1908) dalam Notoatmodjo (2007) pengetahuan merupakan hasil dari tahu, dan ini terjadi setelah orang melakukan pengindraan terhadap suatu objek tertentu.

Hasil penelitian ini didukung oleh penelitian yang di lakukan oleh Rosdewati (2004) terhadap murid SMU di Kabupaten Langat yang menunjukkan bahwa pengetahuan tidak mempunyai hubungan yang bermakna dengan status kesehatan gigi dan mulut. Pengetahuan siswa yang cenderung baik kurang memotivasi siswa untuk bersikap dan melakukan tindakan pemeliharaan kesehatan gigi dan mulut. Mengenai hasil hubungan yang tidak signifikan ini menurut penulis disebabkan karena Copyright @ 2019 Authors, JURNAL KESEHATAN GIGI, e-ISSN 2621-3664, p-ISSN 2407-0866 tingkat pengetahuan anak dengan pemeliharaan kesehatan gigi dan mulut disebabkan karena masih ada murid yang kurang paham dan kurang tahu lebih mendalam tentang kesehatan gigi dan mulut, karena murid kurang memperhatikan materi yang disampaikan oleh tenaga kesehatan dari Puskesmas, maka murid masih kurang memahami lebih jelas tentang pemeliharaan kesehatan gigi dan mulut yang baik dan benar.

Dalam kutipan Atif Fauziah (2015), faktor lingkungan keluarga juga berperan besar dalam mengembangkan pengetahuan anak karena pada dasarnya lingkungan keluarga merupakan wahana pendidikan yang paling besar. Pengetahuan ini erat pula kaitannya dengan sikap seseorang tentang penyakit dan upaya pencegahannya, untuk itu perlu dilakukan kegiatan program usaha kesehatan gigi sekolah dilaksanakan secara rutin minimal 4 kali dalam setahun.

\section{Perilaku Pemeliharaan Kesehatan Gigi dan Mulut}

Berdasarkan tabel 4.4 didapatkan bahwa gambaran perilaku pemeliharaan kesehatan gigi dan mulut $67,8 \%$ yang berkriteria baik, dan 32, $2 \%$ berkriteria cukup dan tidak ada yang berkriteria kurang baik. Teori Skiner (1938) dalam Machfoedz (2007) menyatakan perilaku dapat dibedakan menjadi dua yakni perilaku yang tidak tampak/terselubung (cover behaviour) dan perilaku yang tampak (over behaviour), perilaku yang tidak tampak salah satunya ialah pengetahuan. Menurut Notoadmodjo (2003) bahwa tingkat pengetahuan merupakan domain (kawasan) yang penting agar terbentuknya perilaku seseorang. Menurut Ronger dalam Notoatmodjo (2007) menyimpulkan apa bila penerima perilaku baru atau adopsi perilaku melalui proses yang disadari oleh pengetahuan, kesadaran,dan sikap yang positif maka perilaku tersebut akan bersifat langgeng (long lasting) sebaliknya apabila perilaku itu tidak disadari oleh pengetahuan dan kesadaran maka tidak akan berlangsung lama.

Menurut Bloom (1908) dalam Notoadmojo (2012), status kesehatan gigi dan mulut seseorang atau masyarakat dipengaruhi oleh empat faktor penting yaitu keturunan, lingkungan (fisik maupun sosial budaya), perilaku, dan pelayanan kesehatan. Dari keempat faktor tersebut, perilaku memegang peranan yang penting dalam mempengaruhi status kesehatan gigi dan mulut. Di samping mempengaruhi status kesehatan gigi dan mulut secara langsung, perilaku juga dapat mempengaruhi faktor lingkungan dan pelayanan kesehatan Notoadmodjo (2012). Perilaku pemeliharaan kesehatan gigi dan mulut adalah suatu upaya yang 
dilakukan untuk meningkatkan kesehatan gigi dan mulut perorangan, kelompok dan masyarakat.

Menurut penulis orang tua sangat diperlukan dalam membimbing memberikan pengertian, mengingkatkan dan menyediakan fasilitas kepada anaknya agar dapat meningkatkan perilaku untuk memeliharaan kesehatan gigi dan mulut anaknya.

\section{Hubungan Tingkat Pengetahuan Dengan Perilaku Pemeliharaan Kesehatan Gigi dan Mulut}

Hasil uji statistik menunjukkan bahwa nilai $p$ value $=0,446$, artinya tidak ada hubungan signifikan antara tingkat pengetahuan dengan perilaku pemeliharaan kesehatan gigi dan mulut SDN 36/IV Kota Jambi. Hasil penelitian ini didukung oleh penelitian yang dilakukan oleh Lintang (2015) terhadap siswa SDN Tumaluntung Minahasa Utara menunjukkan bahwa tidak ada hubungan yang kuat antara tingkat pengetahuan dengan perilaku pemeliharaan kesehatan gigi dan mulut. Hal ini terjadi karena pengetahuan anak yang cukup tinggi, dan perilaku anak yang baik, hanya sampai pada tingkat tahu dan memahami saja, selain itu juga , pengetahuan seseorang dapat dipengaruhi oleh beberapa faktor sehingga mengakibatkan pengetahuan tersebut tidak diaplikasikan dalam sebuah tindakan perilaku.

Pengetahuan, kesadaran dan perilaku terhadap pemeliharaan kesehatan gigi dan mulut tersebut dipengaruhi oleh faktor penduduk, lingkungan, tingkat pendidikan, ekonomi dan kehadiran sarana kesehatan serta besar kecilnya pengaruh resiko terhadap timbulnya penyakit gigi dan mulut Suwelo (1992).

\section{Kesimpulan}

Hasil penelitian yang telah dilakukan mengenai tingkat pengetahuan dengan perilaku pemeliharaan kesehatan gigi dan mulut murid SDN 36/IV Kota Jambi dapat disimpulkan bahwa tingkat pengetahuan murid kelas VA dan kelas VB SDN 36/IV Kota Jambi tahun 2018 dengan tingkat pengetahuan tinggi $(66,1 \%)$, dan $(32,2 \%)$ tingkat pengetahuaanya sedang, dan tingkat pengetahuan rendah $(1,7 \%)$. Perilaku pemeliharaan kesehatan gigi dan mulut murid kelas VA dan kelas VB SDN 36/IV Kota Jambi tahun 2018 dengan perilaku pemeliharaan baik $(67,8 \%)$, dan cukup $(32,2 \%)$, dan perilaku pemeliharaan kurang baik tidak ditemukan kriterianya. Tidak ada hubungan yang signifikan antara tingkat pengetahuan dengan perilaku pemeliharaan kesehatan gigi dan mulut murid Kelas V.A dan V.B SD Kota Jambi tahun 2018.

\section{Daftar Pustaka}

[1] Atif, F, Tingkat Pengetahuan tentang Kesehatan Gigi dan Mulut SDN Siswa Kelas IV Tahun 2014/2015. Skripsi Universitas Negeri Yogyakarta, 2015

[2] Budiharto, Ilmu Perilaku Kesehatan dan Pendidikan Kesehatan Gigi. Jakarta . EGC, 1995

[3] Dewanto, H, Aspek-aspek Epidemiologi Maloklusi. Yogyakarta, 1993

[4] Friedman, Keperawatan Keluarga. Yogyakarta: Gosyen Publishing, 2013

[5] Green, LW, Health education planning diagnostic approach. California: Mayfield publishing Company, 1980

[6] Hamada, Menuju Gigi dan Mulut Sehat. Jurnal USU Pencegahan dan Pemeliharaan Kesehatan Gigi dan Mulut. Medan, 2015, 2008

[7] Herijulianti, E. Indriani. TS, Artini. S, Pendidikan Kesehatan Gigi. EGC. Jakarta, 2002

[8] Hidayat, AA, Metode Penelitian Keperawatan dan Teknik Analisis Data. Jakarta: Salemba Medika, 2007

[9] Hidayat, AA, Riset Keperawatan dan Teknik Penulisan Ilmiah. Jakarta; Salemba Medika, 2012

[10] Houwink, B, Dirks, B, Cramwinckel, B.A, Crialaerss, A.J.P, Dermaut, R.L, Eijkman, J.A.M, Veld, J.H.J, Konik, G.K, Moltzer, G, Helderman, P, Pilot, T, Roukema, A.P, Schautteet, H, Tan, H, Veldkamp, V.D.V, Woltgens, Ilmu Kedokteran Gigi Pencegahan, terjemahan 1, Gadjah Mada Universitas Press, Yogyakarta, 1993

[11] Kemenkes RI, Undang-Undang Nomor 36 Tahun 2009 Tentang Kesehatan. Jakarta, 2012

[12] Machfoeds, I, dkk, Menjaga Kesehatan Gigi Mulut Anak dan Ibu Hamil. Yogyakarta. Tramaya, 2005

[13] Ningsi, Perilaku Ibu Terhadap Pemanfaatan Pelayanan Kesehatan Gigi dan Mulut Pada Anak Usia Sekolah. Jakarta, 2013

[14] Notoatmodjo, S, Pendidikan dan Perilaku Kesehatan. Jakarta. Rineka Cipta, 2007

[15] Notoadmodjo, S, Promosi Kesehatan Dan Perilaku Kesehatan. Jakarta. Rineka Cipta, 2012

[16] Pratiwi, D, Gigi Sehat dan Merawat Gigi Sehari-hari. Jakarta, 2007

[17] Praktiknya, AW, Dasar-dasar Metodologi Penelitian Kedokteran dan Kesehatan. PT Raja Grafindo Persada. Jakarta, 2007

[18] Putri, dkk, Ilmu Pencegahan Penyakit Jaringan Keras dan Jaringan Pendukung Gigi. Jakarta, 2011

Copyright @2019 Authors, JURNAL KESEHATAN GIGI, e-ISSN 2621-3664, p-ISSN 2407-0866 
[19] Rahmadhan, A, Serba Serbi Kesehatan Gigi dan Mulut. Jakarta, 2010

[20] Riskesdas RI, Laporan Hasil Riset Kesehatan Dasar(Riskesdas).Kemenkes RI. Jakarta, 2013

[21] Sibagariang, EE , dkk, Metodologi Penelitian Untuk Mahasiswa Diploma Kesehatan . Jakarta, 2010

[22] Sugiyono, Metodologi Penelitian Kuantitatif dan $R \& D$. Bandung Alfabeta, 2010

[23] Suwelo, I.S. 1992. Karies Gigi pada Anak dengan Pelbagai Faktor Etiologi: Kajian pada anak usia prasekolah. EGC, Jakarta

[24] World Health Organization (WHO). Kesehatan Gigi dan Mulut : WHO 2012 